\title{
sciendo
}

\section{PRELIMINARY ASSESSMENT OF INVASIVE LIONFISH Pterois miles USING UNDERWATER VISUAL CENSUS METHOD IN THE NORTHEASTERN MEDITERRANEAN}

\author{
Cemal Turan ${ }^{*}$, Servet Ahmet Doğdu ${ }^{1,2}$
}

${ }^{1}$ Iskenderun Technical University, Faculty of Marine Sciences and Technology, Molecular Ecology and Fisheries Genetics Laboratory, 31220 Iskenderun, Hatay, Turkey

2Iskenderun Technical University, Maritime Vocational School of Higher Education, Underwater Technologies, Iskenderun, Hatay, Turkey

*Corresponding author: cemal.turan@iste.edu.tr

\section{ARTICLE INFO}

Received: 11 May 2021

Accepted: 21 December 2021

\section{Keywords:}

invasive alien species

lionfish

monitoring

Mediterranean coast of Turkey

underwater visual census

How to Cite

\begin{abstract}
Underwater visual census (UVC) is a commonly used approach for assessing fish density and biomass. Iskenderun Bay, comprising the Samandağ coast in Turkey, is the most important introduction pathway of alien species in the northeastern Mediterranean. In this study, the density, abundance, distribution and interaction of invasive lionfish or devil firefish Pterois miles were assessed using the UVC method on the Samandağ coast. The total transect area monitored on the Samandağ coast was $4.500 \mathrm{~m}^{2}$. Species richness, Shannon's diversity index and rate of biomass were $25,1.81$ and $73.5 \mathrm{~m}^{2}$, respectively. Reduced diversity was observed with increasing depths. The sandy seafloor was a limiting factor for lionfish distribution. There was a significant positive correlation between lionfish total density and both the Shannon diversity index $(r=0.99, P<0.001)$ and Shannon evenness index $(r=0.99, P<0.05)$. A high number of significant positive correlations $(P<0.05)$ were detected between the occurrence of lionfish and the occurrence of both the native species and other alien species. The first stock assessment study of lionfish by the UVC method in Turkish marine waters revealed that native species are under very high pressure from lionfish species, especially Chromis, Sparids and Wrasses, indicating negative effects of lionfish on regional native biodiversity.
\end{abstract}

Cemal Turan, C., Doğdu, S. A. (2022). Preliminary assessment of invasive lionfish Pterois miles using underwater visual census method in the Northeastern Mediterranean. Croatian Journal of Fisheries, 80, 38-46. 1. DOI: $10.2478 /$ cjf-2022-0005. 


\section{INTRODUCTION}

Biodiversity in the Mediterranean Sea has been considerably altered since the opening of the Suez Canal in 1869 which favored the settlement and spread of lessepsian/erythrean fish and invertebrates in the Mediterranean basin, and which appears to be accelerating (Dalyan et al., 2014; Doğdu et al., 2016; Turan et al., 2016; Gürlek et al., 2016a; Castellanos-Galindo et al., 2020; D'Amen and Azzurro, 2020; Fitori et al., 2021). Tortonese (1964) estimated there were about 30 IndoPacific immigrant fish species in the Mediterranean, from a total of about 550. In the Atlas of Exotic Species in the Mediterranean, Golani et al. (2002) reported 59 exotic fish species from an estimated total of 650 in the Mediterranean, which is almost $10 \%$ of the population. The checklist of Zenetos et al. (2010) comprises 106 alien fish species of Indo-Pacific origin in the Mediterranean. Turan et al. (2018) produced a checklist of 101 nonindigenous marine fish, including bony, cartilaginous and jawless species distributed along Turkish marine waters, of which 89 were bony, 11 cartilaginous and 1 jawless. In terms of the occurrence of non-indigenous fish species in Turkish marine waters, the Mediterranean coast has the highest diversity (92 species), followed by the Aegean Sea (50 species), the Marmara Sea (11 species) and the Black Sea (2 species).

Lionfish Pterois miles (Bennett 1828) have high invasive character and threat to the native biodiversity in the invaded areas of the eastern Atlantic, the Caribbean, the Gulf of Mexico and recently the Mediterranean Sea (Turan et al., 2014; Turan and Öztürk, 2015). Through their predation on native species, lionfish were predicted to have long-term effects on the structure and function of Mediterranean ecosystems (Turan, 2020; Turan et al., 2020). The density, biomass and distribution of lionfish must be fully understood to design and implement the most effective way of control. Thus, it is important to assess the current status of lionfish as well as other Invasive Alien Species (IAS) to contribute to management plans by identifying site-specific measures for prevention, control and management of IAS. For this reason, monitoring and providing data on IAS in relevant habitats is the first step in establishing such measures.

Underwater visual census (UVC) is an approach for assessing the density and biomass of fishes (Edgar et al., 2004; Kulbicki et al., 2012). UVCs are primarily conducted using scuba and encompass a range of methods, such as UVC strip transects (Murphy and Jenkins, 2010). At first, UVC has been developed for use in the studies of tropical coral reef fish (Brock, 1954). Nowadays, the application of UVC is widespread in temperate waters, such as the Mediterranean Sea. It has been successfully applied in marine protected areas (MPAs), as well as in other important marine habitats, such as rocky reefs, submarine caves and seagrass meadows (Tunesi et al., 2006; Bussotti and Guidetti, 2009; Soldo and Glavičić, 2020), just to mention a few. Bias in detection across time and space could prove especially problematic for species for which accurate estimates of density and biomass are needed to inform environmental managers (Green et al., 2013).

Iskenderun Bay, comprising the Samandağ coast, is the most important introduction pathway of invasive alien species in Turkish marine waters (Nunes et al., 2014). Lionfish species Pterois miles is highly abundant in this area but there is no data on the abundance, density and interaction of these species in this region. Besides, in Turkish marine waters, it is important to know to control and/or decrease the abundance of these species in this region as well as other coastal waters of Turkey.

In this study, we aimed to assess lionfish Pterois miles density, abundance, distribution and interaction with native species using the UVC method in the Samandag coast, northeastern Mediterranean Sea.

\section{MATERIALS AND METHODS}

\section{Study regions}

The study region, the Samandağ coast (36 $\left.00^{\prime} 08.0^{\prime \prime} \mathrm{N}, 35^{\circ} 58^{\prime} 24.7^{\prime \prime} \mathrm{E}-36^{\circ} 00^{\prime} 04.6^{\prime \prime} \mathrm{N}, 35^{\circ} 58^{\prime} 18.7^{\prime \prime} \mathrm{E}\right)$, Iskenderun Bay, the northeast Mediterranean Sea, was chosen for the monitoring based on the biodiversity importance of marine area being a spawning and feeding ground of elasmobranch species (sharks, rays and skates), hatching beach of sea turtles (Chelonia mydas and Caretta caretta), spawning and feeding ground of grouper species Epinephelus spp., and breeding area of the Mediterranean monk seal Monachus monachus.

\section{Transect surveys}

UVC strip transect (Labrosse et al., 2002; Edgar et al., 2004; Whitfield et al., 2007; Kulbicki et al., 2012; Agudo and Salas, 2014) was used to quantify the density, abundance and distribution of lionfish in the studied areas. Transect data can reveal species zonation patterns along the line by showing where particular species occur on the line and also how many are present at any point along the line. The method consists of on-site visual counts of organisms by scuba diving along a rectangular transect (measuring tape laid on the sea bottom); in this study, the length and width of the transect were $50 \mathrm{~m}$ and $5 \mathrm{~m}$, respectively.

A standardized underwater visual census protocol for surveying lionfish in the Samandağ coast was set according to Whitfield et al. (2007) and Murphy et al. (2010). Three depth ranges from deep to shallow - deep (21-30 m), middle (11-20 $\mathrm{m}$ ) and shallow (5-10 $\mathrm{m})$ - were monitored by two divers. For each depth category, three $5 \mathrm{~m}$ x $50 \mathrm{~m}$ replicate transects were screened by each diver, covering an area of $500 \mathrm{~m}^{2}$ for each transect by two divers. Fish were recorded by genus and species, where possible, in numbers. The size of lionfish was recorded in the following 
classes (to the nearest $\mathrm{cm}$ ): 10, 11-20, 21-30, 31-40 and $>40$ using an underwater pointer. Lionfish smaller than $3 \mathrm{~cm}$ are omitted to standardize density comparisons. The observer slightly adjusted his swimming rate (15-20 $\mathrm{min} /$ transect), and transects with high fish densities were sampled more slowly than those with low densities. Fish counts are conducted during high neap tides, as the lower movement of the water means it is less likely for the fish to hide.

\section{Data analysis}

Density data was converted to wet weight as $\mathrm{g} / \mathrm{m}^{2}$ using standard L-W conversions, with published $a$ and $b$ values. Two main components contribute to biodiversity-species richness $(\mathrm{S})$ and species evenness (E). Species richness describes the number of different species present in an area (more species $=$ greater richness). Species evenness describes the relative abundance of different species in an area (similar abundance $=$ more evenness).

The Shannon diversity index $(\mathrm{H})$ was used to characterize species diversity in a community (Shannon and Weaver, 1949).

$H=\sum\left[\left(p_{\mathrm{i}}\right) \times \ln \left(p_{\mathrm{i}}\right)\right]$

Shannon's index accounts for both the abundance and evenness of the species present. The proportion of species relative to the total number of species (pi) is calculated and then multiplied by the natural logarithm of this proportion $\left(\ln p_{i}\right)$.

Species evenness refers to how close in numbers the community is. Shannon's evenness index $\left(E_{H}\right)$ can be calculated by dividing $H$ by $H_{\max }$. Equitability assumes $a$ value between 0 and 1 with 1 being complete evenness.

$\mathrm{E}=\frac{H}{H_{\max }}$

To estimate lionfish body mass, we converted individual lionfish lengths ( $T L$ in $\mathrm{cm}$ ) to weights, using the allometric relationship:

$\mathrm{W}_{\mathrm{t}}=\mathrm{aL}^{\mathrm{b}}$

where $\mathrm{W}_{\mathrm{t}}=$ weight, $\mathrm{L}=$ fish length, $\mathrm{a}$ and $\mathrm{b}$ are constants. The constants $a$ and $b$, which were reported for lionfish species $P$. miles in Iskenderun Bay by Dağhan and Demirhan (2020), was used in this conversion.

Biomass, which is fresh weight per surface area unit (gr/ $\mathrm{m}^{2}$ ), was calculated using the individual mean weights and abundances;

$\mathrm{B}=\frac{\sum_{i=1}^{p} w i}{a}$

where $w=$ weight of fish (individuals) of a species and $a$ = census area. Each data record consists of an estimated weight for each fish.

For a lionfish species, the estimate of the mean density

(D) on a transect is expressed as:

$$
\mathrm{D}=\frac{\sum_{i=1} n_{i}}{a}
$$

where $\mathrm{n}$ is the number of lionfish seen and $\mathrm{a}=$ census area (Whitfield et al., 2007). All statistical analyses were performed in R-Studio.

\section{Statistical analysis}

All statistical analyses were performed in R-Studio and graphics were produced using the ggplot2 package. QGIS was used for statistical geographic information (GIS) presentations. A two-factor permutation analysis of variance (PERMANOVA), based on Euclidean distance, and Analysis of Variance (ANOVA) were used to test the null hypothesis of no differences in lionfish density, biomass and other biological parameters.

\section{RESULTS AND DISCUSSION}

The total transect area monitored on the Samandağ coast was $4.500 \mathrm{~m}^{2}$. The species richness was 25 , and Shannon diversity and evenness indices were 1.81 and 0.67 , respectively. Mean biomass and mean density comprising all depths were $7.34 \mathrm{~g} / \mathrm{m}^{-2}$ and $0.024 \mathrm{n} / \mathrm{m}^{-2}$, respectively. The observed Shannon diversity index of IAS species is higher than for the Mediterranean species. Albins (2015) and Benkwitt (2015) studied lionfish Pterois volitans distribution in the Bahamas and reported Shannon's index as $0.826 \mathrm{~kg} / \mathrm{ha}^{-1}$ and $0.322 \mathrm{~kg} / \mathrm{ha}^{-1}$, respectively, which was lower than in the present study.

Alien species, Parupeneus forsskali, Diadema setosum and Sargocentron rubrum, were observed as the first three species with the highest frequency species (Fig. 1). Significant differences were found in the composition of each species with depth distribution. The species are mainly located at a depth between $8 \mathrm{~m}$ and $15 \mathrm{~m}$ (Fig. 2). P. forsskali, Pomadasys stridens and Cassiopeia nomadica were the most abundant species at 5-10 m, 10.1-20 m and 20.1-30 m, respectively. Interestingly, all these species were IAS. At the depth of $>20 \mathrm{~m}$, the seafloor was sandy, which limited the species richness even for lionfish. Only the upside-down jellyfish was recorded at this depth.

Collectively for the whole depth zone (5-30 m), the mean biomass was $7.34 \mathrm{~g} / \mathrm{m}^{-2}$. However, there is an apparent difference among the depths of $8 \mathrm{~m}, 15 \mathrm{~m}$ and $25 \mathrm{~m}$ where biomass was found to be $8.96 \mathrm{~g} / \mathrm{m}^{-2}, 13,08 \mathrm{~g} / \mathrm{m}^{-2}$ and 0.0 $\mathrm{g} / \mathrm{m}^{-2}$, respectively. The increasing biomass of lionfish was increasing at $8 \mathrm{~m}$ and $15 \mathrm{~m}$ in parallel (Fig. 3). The sizes of 21-30 cm and above $41 \mathrm{~cm}$ showed the highest biomass at the depths of $8 \mathrm{~m}$ and $15 \mathrm{~m}$, respectively (Fig. 3). There were no lionfish recorded at the depth of $25 \mathrm{~m}$ with a sandy bottom structure.

The mean density including all depths was $0.073 \mathrm{n} / \mathrm{m}^{-2}$, of which $0.038 \mathrm{n} / \mathrm{m}^{-2}$ and $0.035 \mathrm{n} / \mathrm{m}^{-2}$, and $0.0 \mathrm{n} / \mathrm{m}^{-2}$ for the depths $0-8 \mathrm{~m}$ and $8.1-15 \mathrm{~m}$, and $15.1-25 \mathrm{~m}$, respectively. The highest and lowest density of lionfish was observed 


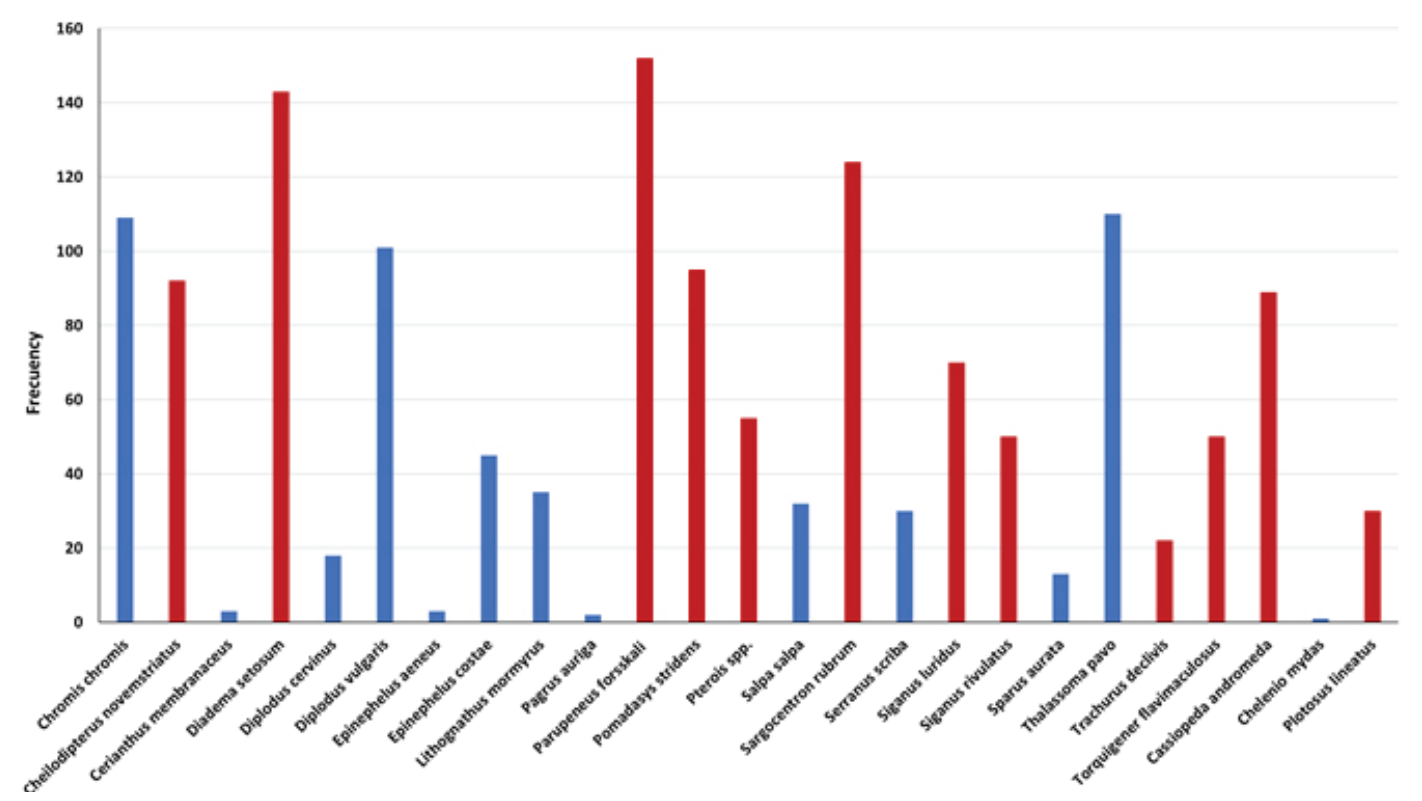

Fig. 1. Frequency of all monitored species at all study regions (Red colour: IAS, Blue colour: Mediterranean fish species)

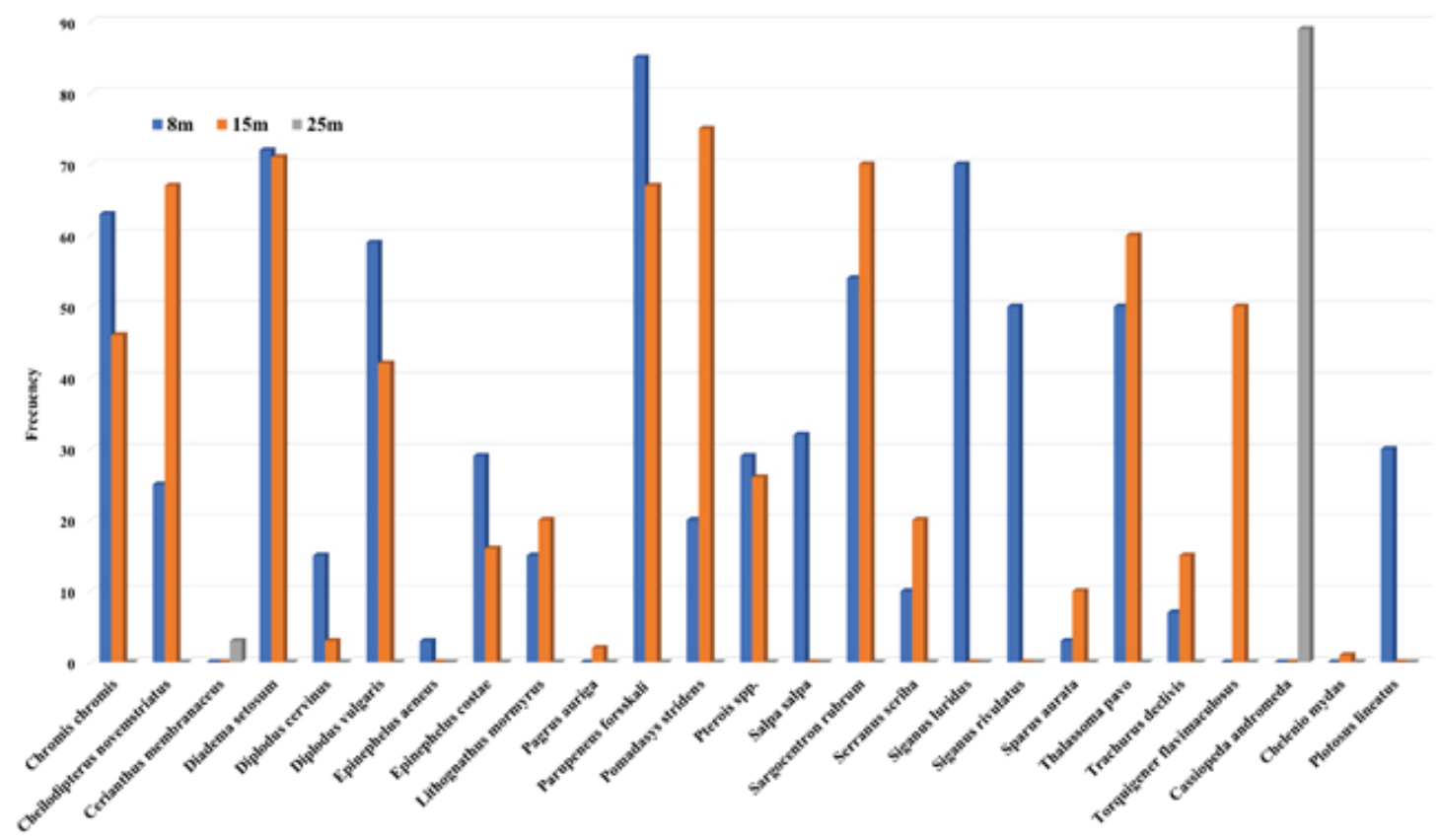

Fig. 2. The composition of monitored species with depth distribution in the study region 


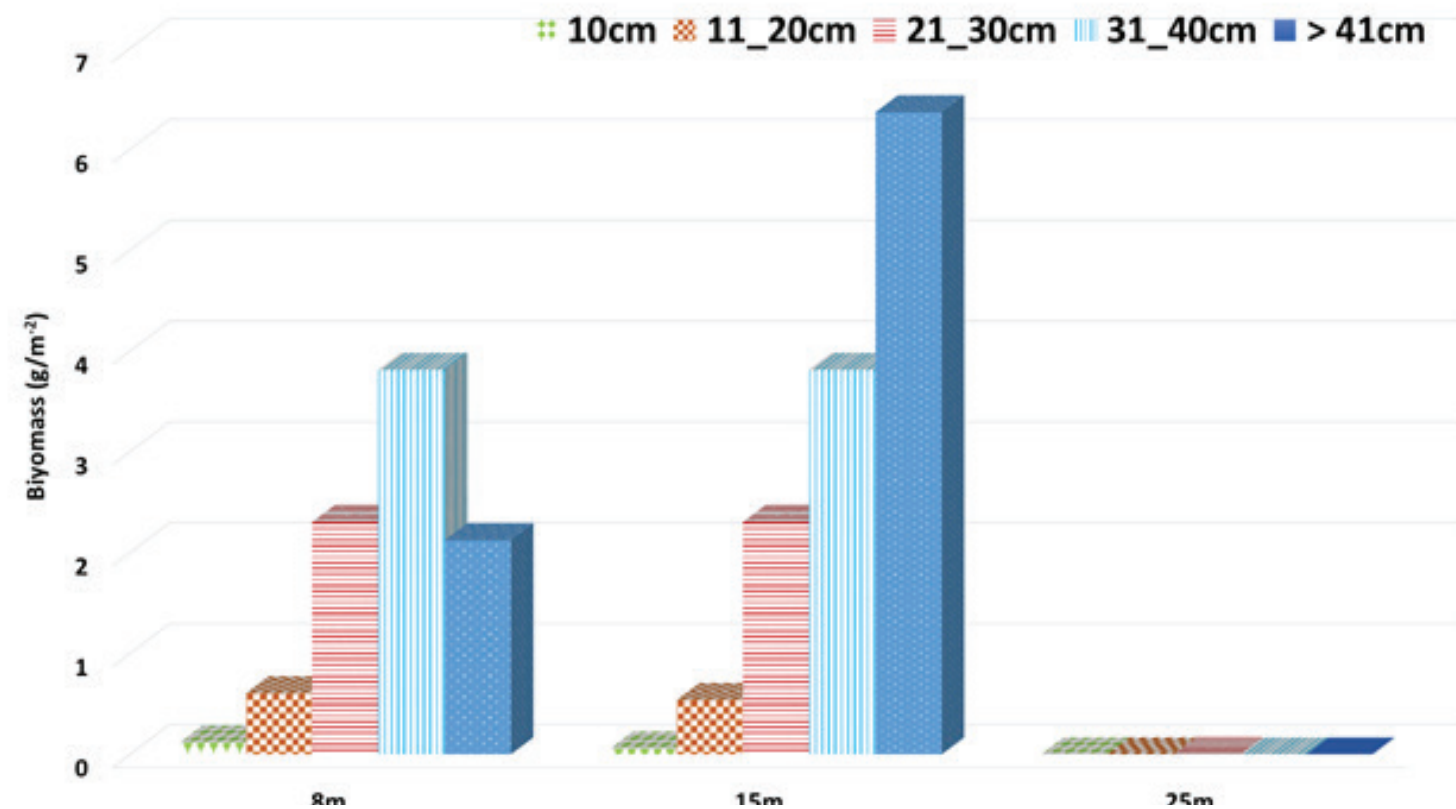

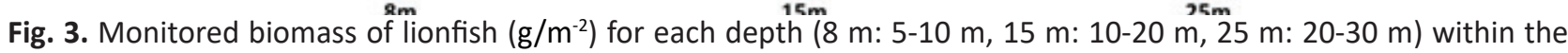
study region

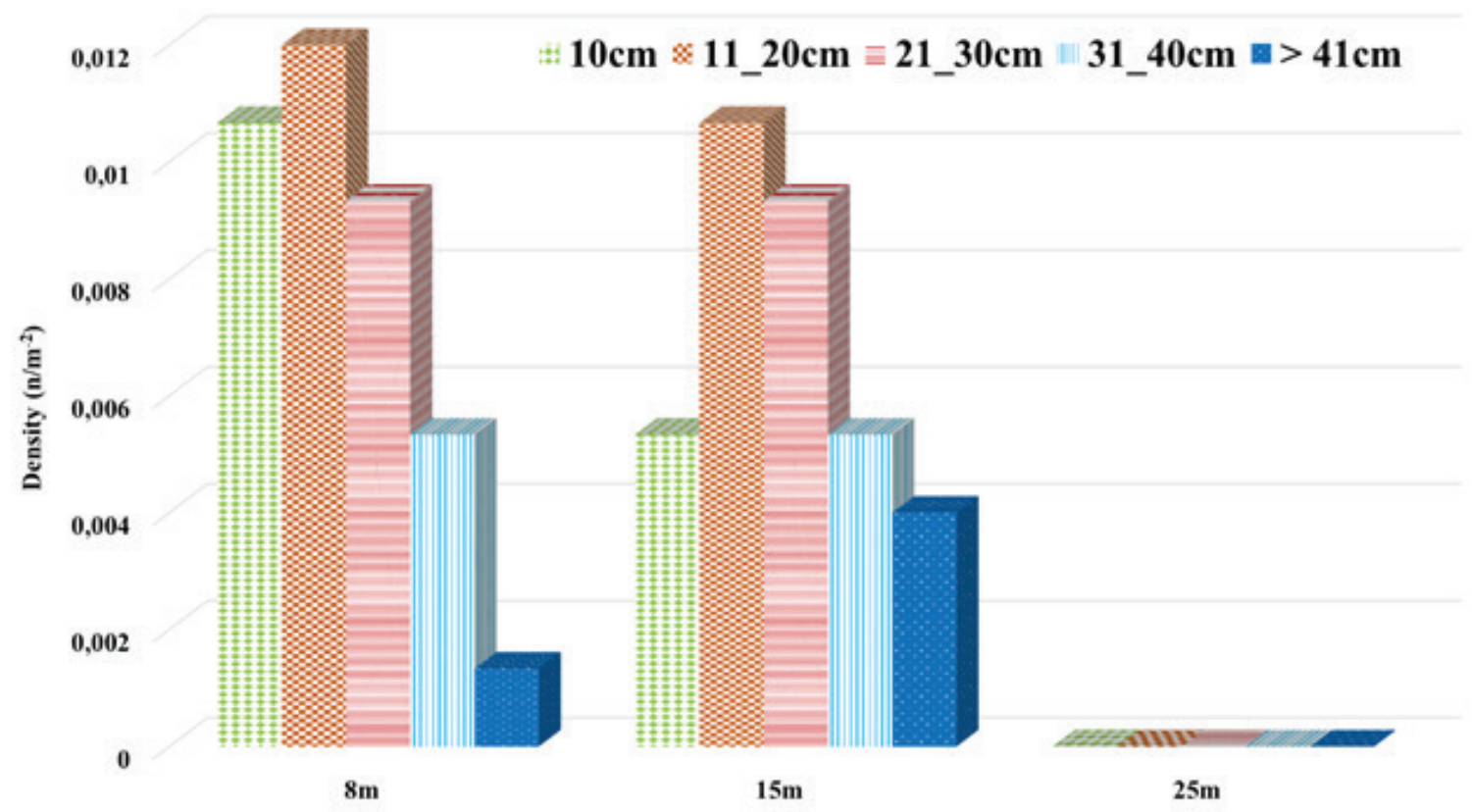

Fig. 4. The monitored density of lionfish $\left(\mathrm{n} / \mathrm{m}^{-2}\right)$ for each depth (8 m: 5-10 m, $\left.15 \mathrm{~m}: 10-20 \mathrm{~m}, 25 \mathrm{~m}: 20-30 \mathrm{~m}\right)$ within the study region 
for $11-20 \mathrm{~cm}$ and over $41 \mathrm{~cm}$ size classes both at the depths of $8 \mathrm{~m}$ and $15 \mathrm{~m}$, respectively (Fig. 4), which is in accordance with species richness at these depths (Fig. 1). Adjeroud et al. (1998) reported the density of $P$. miles in the Mauritius coast as $3 \mathrm{n} / \mathrm{ha}^{-1}$. Letourneur et al. (2008) reported the density of $P$. miles in the Indian Ocean as $6.2 \mathrm{n} / \mathrm{ha}^{-1}$. Darling et al. (2011) studied lionfish in Kenya and observed a total density of $P$. miles as $25.1 \mathrm{n} / \mathrm{ha}^{-1}$ and biomass as $1.5 \mathrm{n} / \mathrm{ha}^{-1}$. The density and biomass in the Atlantic and Pacific Oceans mentioned above is much higher than that found in this study for the Mediterranean. This might be due to high availability of small fishes and a decrease of top predators (Epinephelus marginatus and Octopus vulgaris) as a result of overfishing in the Mediterranean Sea (Condini et al., 2017; Evliyaoğlu et al., 2020).

The proportion of lionfish P. miles among all 25 IAS (25 species) was $3.7 \%$. The sandy seafloor seems to be a limiting factor for lionfish distribution. This can be explained by two reasons. First, there is a low number of fish species on the sandy ground which is not preferable for the lionfish that has continuous feeding habits. Secondly, lionfish also has a hiding behaviour. Therefore, they prefer habitats with reefs, caves and big rocks for feeding. There was a significant positive correlation between lionfish total density $\left(\mathrm{m}^{2}\right)$ and Shannon diversity index $(\mathrm{H})(\mathrm{r}=$ $0.99, P<0.001$ ), which indicates that the number of lionfish increases with increased species diversity. Moreover, there was also a significant positive correlation between lionfish total density $\left(\mathrm{m}^{2}\right)$ and Shannon evenness index $(r$ $=0.99, P<0.05)$, indicating that the increased abundance of each species is directly related to the abundance of lionfish.

It is important to understand the relationship between the occurrence of lionfish and other species in order to generate strategies for challenging lionfish. A high number of significant positive correlations were detected between the occurrence of lionfish, other native species and IAS (Fig. 5), indicating that lionfish put pressure on both. Our observations and another study showed that

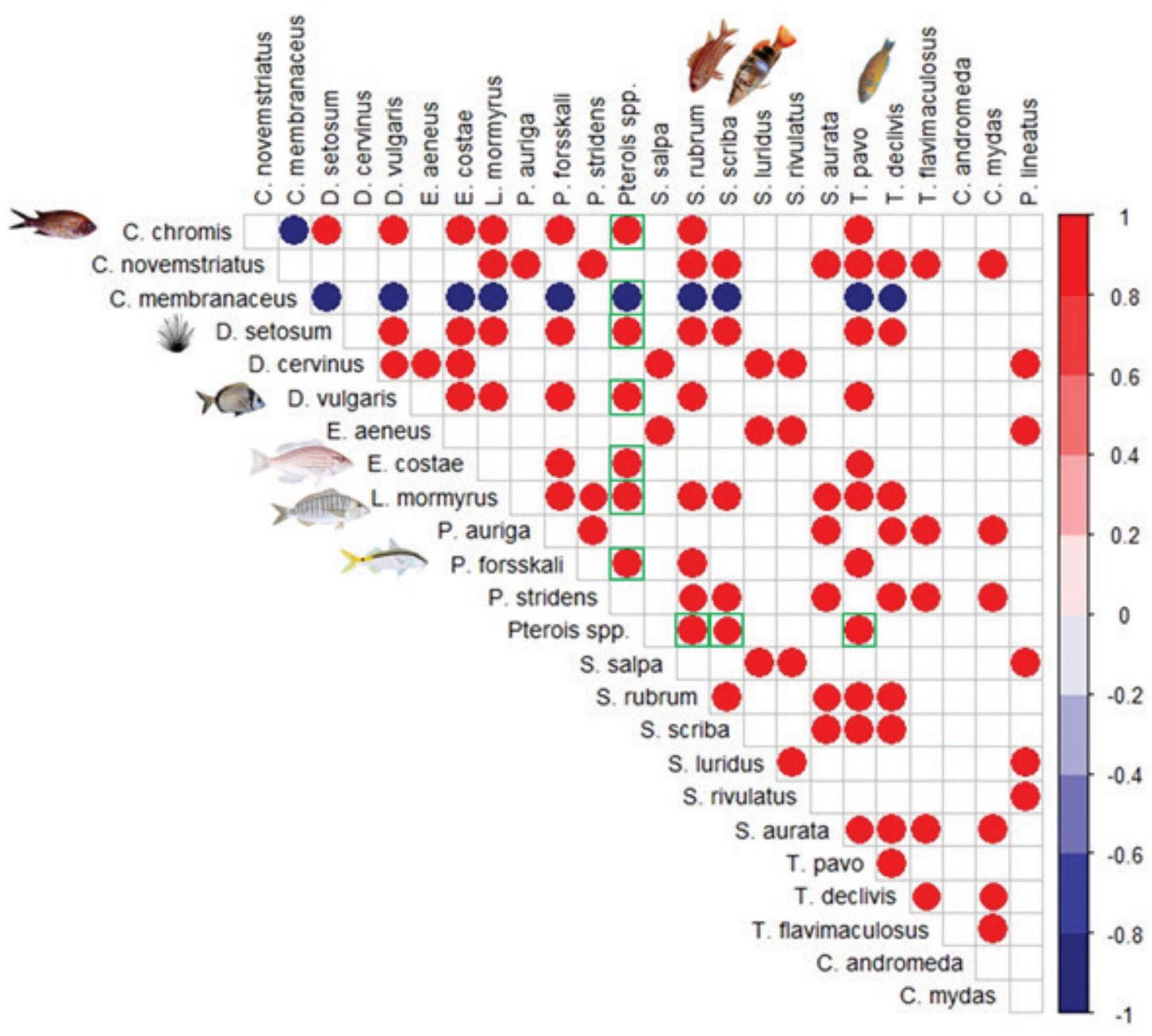

Fig. 5. Pearson correlations, showing the relationship of species occurrence. Only statistically significant $(P<0.5)$ correlations between species were redpointed with its magnitude of correlation. The significant correlations of lionfish with other species are indicated by green squares. 
the diet of lionfish may consist of labrids, pomacentrids, sparids and other IAS (Zannaki et al., 2019). Especially, Sparid, Wrasse, Grouper and Chromis species seems to be threatened by lionfish. Moreover, the only significant negative correlation for the occurrence of lionfish was observed with Cheilodipterus novemstriatus.

In conclusion, the first stock assessment study of lionfish by the UVC method in Turkish marine waters revealed that there is a high density and biomass of lionfish in the region, which is negatively affecting regional native biodiversity as confirmed by other studies (Hixon et al., 2016; Sabido-Itzá and García-Rivas, 2019). The density and biomass of lionfish found in this study for the Mediterranean were much higher than that for the Atlantic and Pacific Oceans, which might be due to the high availability of small fishes and decrease of top predators as a result of overexploitation in the Mediterranean. The sandy seafloor seems to be a limiting factor for lionfish distribution. The lionfish abundance increases with increased species diversity and evenness. Controlling the distribution and abundance of lionfish in the region is a necessary measure for the perpetuation of native species as a management consideration.

\section{ACKNOWLEDGEMENTS}

This study was supported by the MarlAS Project (Addressing Invasive Alien Species Threats at Key Marine Biodiversity Areas Project), which is being implemented by the Directorate-General for Nature Conservation and National Parks under the Ministry of Agriculture and Forestry and UNDP with the financial support of Global Environment Facility (GEF).

\section{PRELIMINARNA PROCJENA INVAZIVNOG PRUGASTOG KOKOTA Pterois miles METODOM PODVODNE VIZUALIZACIJE NA SJEVEROISTOČNOM MEDITERANU}

\section{SAŽETAK}

Podvodna vizualizacija (UVC) je uobičajeni pristup za procjenu gustoće ribe i biomase. Zaljev Iskenderun, kojeg okružuje obalno područje Samandağ u Turskoj, najvažniji je put unošenja stranih vrsta u sjeveroistočni Mediteran. U ovoj studiji, gustoća, brojnost, distribucija i interakcija invazivnog prugastog kokota Pterois miles procijenjene su UVC metodom na obali Samandağ. Ukupna promatrana površina transekta na obali Samandağ iznosila je 4.500 $\mathrm{m}^{2}$. Bogatstvo vrsta, Shanonov indeks raznolikosti i stopa biomase iznosili su 25, 1,81 i 73,5 m². Uočena je smanjena raznolikost s povećanjem dubine. Pješčano morsko dno bilo je ograničavajući čimbenik za distribuciju ove vrste.
Postojala je značajna pozitivna korelacija između ukupne gustoće vrste i Shannonovog indeksa raznolikosti $(r=$ $0,99, P<0,001)$ i Shannonovog indeksa ravnomjernosti $(r$ $=0,99, P<0,05)$. Utvrđen je veliki broj značajnih pozitivnih korelacija $(P<0,05)$ između pojave prugastog kokota i pojave domaćih i drugih stranih vrsta. Prva studija procjene zaliha ove vrste metodom UVC u turskim morskim vodama otkrila je da su autohtone vrste pod vrlo visokim pritiskom od stranih vrsta, posebno rodova Chromis, Sparids i Wrasses, što ukazuje na negativne učinke prugastog kokota na regionalnu autohtonu biološku raznolikost.

Ključne riječi: invazivne strane vrste, prugasti kokot, monitoring, mediteranska obala Turske, podvodni vizualni popis

\section{REFERENCES}

Adjeroud, M., Letourneur, Y., Porcher, M., and Salvat, B. (1998): Factors influencing spatial distribution of fish communities on a fringing reef at Mauritius, SW Indian Ocean. Environmental Biology of Fishes, 53(2), 169182.

Agudo, E., Klein Salas, E. (2014): Lionfish abundance, size structure and spatial distribution along the Venezuelan coast (Pterois volitans, Pteroinae: Scorpaenidae): Revista de Biología Tropical, 62, 401-407.

Albins, M. A. (2015): Invasive Pacific lionfish Pterois volitans reduce abundance and species richness of native Bahamian coral-reef fishes. Marine Ecology Progress Series, 522: 231-243.

Benkwitt, C. E. (2015): Non-linear effects of invasive lionfish density on native coral-reef fish communities. Biological Invasions, 17(5), 1383-1395.

Brock, V. E. (1954): A preliminary report on a method of estimating reef fish populations. The Journal of Wildlife Management, 18(3), 297-308.

Bussotti, S., Guidetti, P. (2009): Do Mediterranean fish assemblages associated with marine caves and rocky cliffs differ?. Estuarine, Coastal and Shelf Science, 81(1), 65-73.

Castellanos-Galindo, G. A., Robertson, D. R., Torchin, M. E. (2020): A new wave of marine fish invasions through the Panama and Suez canals. Nature Ecology \& Evolution, 4(11), 1444-1446.

Condini, M. V., García-Charton, J. A., Garcia, A. M. (2018): A review of the biology, ecology, behavior and conservation status of the dusky grouper, Epinephelus marginatus (Lowe 1834): Reviews in Fish Biology and Fisheries, 28(2), 301-330.

D’Amen, M., Azzurro, E. (2020): Lessepsian fish invasion in Mediterranean marine protected areas: a risk assessment under climate change scenarios. ICES Journal of Marine Science, 77(1), 388-397.

Dağhan, H., Demirhan, S. A. (2020): Some bio-ecological characteristics of lionfish Pterois miles (Bennett, 1828) 
in Iskenderun Bay. Marine and Life Sciences, 2(1): 2840. (In Turkish).

Dalyan, C., Yemisken, E., Erguden, D., Turan, C., Eryilmaz, L. (2014): Short communication First record of the Indian Ocean anchovy Stolephorus insularis Hardenberg, 1933 from the northeastern Mediterranean coast of Turkey. Journal of Applied Ichthyology, 30(5), 1039-1040.

Darling, E. S., Green, S. J., O'Leary, J. K., Côté, I. M. (2011): Indo-Pacific lionfish are larger and more abundant on invaded reefs: a comparison of Kenyan and Bahamian lionfish populations. Biological Invasions, 13(9), 20452051.

Doğdu, S. A., Uyan, A., Uygur, N., Gürlek, M., Ergüden, D., Turan, C. (2016): First record of the Indo-Pacific striped eel catfish, Plotosus lineatus (Thunberg, 1787) from Turkish marine waters. Natural and Engineering Sciences, 1(2), 25-32.

Edgar, G. J., Barrett, N. S., Morton, A. J. (2004): Biases associated with the use of underwater visual census techniques to quantify the density and size-structure of fish populations. Journal of Experimental Marine Biology and Ecology, 308(2), 269-290.

Evliyaoğlu, E., Eroldoğan, O. T., Yılmaz, H. A., Genç, M. A., Genç, E., Duncan, N., Güroy, D. (2019): Artificial sex reversal of white grouper (Epinephelus aeneus) utilizing aromatase inhibitor (Fadrozole): Aquaculture Research, 50(5), 1539-1546.

Fitori, A., Mahdy, A., Said, R. E., Al-Faturi, A. (2021): The first record of the lessepsian migrant Pteragogus trispilus Randall 2013 (Osteichthyes: Labridae) off the Libyan coast, east Mediterranean Sea. The Egyptian Journal of Aquatic Research. (In press)

Golani, D., Orsi-Relini, L., Massuti, E., Quignard, J. P. (2002): CIESM Atlas of exotic species in the Mediterranean: Vol 1: Fishes. CIESM.

Green, S. J., Tamburello, N., Miller, S. E., Akins, J. L., Côté, I. M. (2013): Habitat complexity and fish size affect the detection of Indo-Pacific lionfish on invaded coral reefs. Coral Reefs, 32(2), 413-421.

Gürlek, M., Ergüden, D., Uyan, A., Doğdu, S. A., Yağlıoğlu, D., Öztürk, B., Turan, C. (2016a): First record red lionfish Pterois volitans (Linnaeus, 1785) in the Mediterranean Sea. Natural and Engineering Sciences, 1(3), 27-32.

Hixon, M. A., Green, S. J., Albins, M. A., Akins, J. L., Morris Jr, J. A. (2016): Lionfish: a major marine invasion. Marine Ecology Progress Series, 558, 161-165.

Kulbicki, M., Beets, J., Chabanet, P., Cure, K., Darling, E., Floeter, S. R., Letourneur, Y. (2012): Distributions of Indo-Pacific lionfishes Pterois spp. in their native ranges: implications for the Atlantic invasion. Marine Ecology Progress Series, 446, 189-205.

Labrosse, P., Kulbicki, M., Ferraris, J. (2002): Underwater visual fish census surveys: Proper use and implementation.FAO.

Letourneur, Y., Gaertner, J. C., Durbec, J. P., Jessu, M. E. (2008): Effects of geomorphological zones, reefs and seasons on coral reef fish communities of Réunion
Island, Mascarene Archipelago, SW Indian Ocean. Estuarine, Coastal and Shelf Science, 77(4), 697-709.

Murphy, H. M., Jenkins, G. P. (2010): Observational methods used in marine spatial monitoring of fishes and associated habitats: a review. Marine and Freshwater Research, 61(2), 236-252.

Nunes, A. L., Katsanevakis, S., Zenetos, A., Cardoso, A. C. (2014): Gateways to alien invasions in the European seas. Aquatic invasions, 9(2), 133-144.

Sabido-Itzá, M. M., García-Rivas, M. D. C. (2019): Record of abundance, spatial distribution and gregarious behavior of invasive lionfish Pterois spp. (Scorpaeniformes: Scorpaenidae) in coral reefs of Banco Chinchorro Biosphere Reserve, southeastern Mexico. Latin american journal of aquatic research, 47(2), 349-355.

Shannon, C. E., Weaver, W. (1949): A mathematical model of communication. Urbana, IL: University of Illinois Press, 11.

Soldo, A., Glavičić, I. (2020): Underwater Visual Census of Deeper Vertical Rocky Reefs. Turkish Journal of Fisheries and Aquatic Sciences, 20(11), 785-794.

Tortonese, E. (1964): The main biogeographical features and problems of the Mediterranean fish fauna. Copeia, 98-107.

Tunesi, L., MoLinAri, A., Salvati, E., Mori, M. (2006): Depth and substrate type driven patterns in the infralittoral fish assemblage of the NW Mediterranean Sea. Cybium, 30(2), 151-159.

Turan, C. (2020): Species distribution modelling of invasive alien species; Pterois miles for current distribution and future suitable habitats. Global Journal of Environmental Science and Management, 6 (4), pp. 429-440.

Turan, C., Ergüden, D., Gürlek, M., Yağlıoğlu, D., Uyan, A., Uygur, N. (2014): First record of the Indo-Pacific lionfish Pterois miles (Bennett, 1828)(Osteichthyes: Scorpaenidae) for the Turkish marine waters. Journal of Black Sea/Mediterranean Environment, 20(2), 158163.

Turan, C., Öztürk, B. (2015): First record of the lionfish Pterois miles (Bennett 1828) from the Aegean Sea. Journal of the Black Sea/Mediterranean Environment, 20(2), 334-388.

Turan, C., Ergüden, D., Gürlek, M. (2016): Climate change and biodiversity effects in Turkish Seas. Natural and Engineering Sciences, 1(2), 15-24.

Turan, C., Gürlek, M., Başusta, N., Uyan, A., Doğdu, S., Karan, S. (2018): A Checklist of the Non-indigenous Fishes in Turkish Marine Waters. Natural and Engineering Sciences, 3(3), 333-358.

Turan, C., Uyan, A., Gürlek, M., Doğdu, S. A. (2020): DNA Barcodes for Identifications of Two Lionfish Species Pterois miles (Bennett, 1828) and Pterois volitans (Linnaeus, 1758) in the Mediterranean. FishTaxa, 16, 29-36.

Whitfield, P. E., Hare, J. A., David, A. W., Harter, S. L., 
Munoz, R. C., Addison, C. M. (2007): Abundance estimates of the Indo-Pacific lionfish Pterois volitans/ miles complex in the Western North Atlantic. Biological Invasions, 9(1), 53-64.

Zannaki, K., Corsini-Foka, M., Kampouris, T. E., and Batjakas, I. E. (2019): First results on the diet of the invasive Pterois miles (Actinopterygii: Scorpaeniformes: Scorpaenidae) in the Hellenic waters. Acta Ichthyologica et Piscatoria, 49(3), 311-317.

Zenetos, A., Gofas, S., Verlaque, M., Çinar, M. E., Raso, J. G., Bianchi, C. N., Siokou, I. (2010): Alien species in the Mediterranean Sea by 2010. A contribution to the application of the European Union's Marine Strategy Framework Directive (MSFD): Part I. Spatial distribution. Mediterranean Marine Science, 11(2), 381. 